\title{
Effect of Work Life Balance \& Antecedent Variable on Intention to Stay (A Study of Female Employees in High Performing Banks in Jakarta)
}

\author{
Sylvia Diana Purba \\ Atma Jaya Chatolic University -Jakarta Indonesia \\ Jln. Jend. Sudirman No.51 Jakarta Indonesia 12930 \\ Tel.+62-021-5708815 ext.2157 \\ E-mail: sylvia.purba@atmajaya.ac.id or selvypurba@yahoo.com
}

\begin{abstract}
This research raised a topic about Work-Life Balance (WLB) and the antecedent variable towards Intention to Stay. This study was conducted on 154 female respondents who worked as bank employees in the best-performing banks in Jakarta by purposive sampling method as married women whose have children and has been working more than 3 years. WLB which stated in respondent perception found that is positively influenced towards Intention to Stay, where Management of Dual Role and The Organizational Support Practices is the antecedent variable of WLB. Consequently, Management of Dual Role in fact is not influenced towards Intention to Stay meanwhile The Organizational Support Practices still influenced $10 \%$ of Alpha. The interesting finding in this research known that WLB influenced by Management of Dual Role used house-maid service and The Organizational Support Practices have not touched the support towards Dual Role Women. It is described that the organization has not been supported the WLB issue.
\end{abstract}

Keywords: Work-Life Balance, Management of Dual Role, The Organizational Support Practices, Intention to Stay

\section{Council for Innovative Research}

Peer Review Research Publishing System

Journal: International Journal of Management \& Information Technology

Vol. 8, No. 3

editor@cirworld.com

www.cirworld.com, member.cirworld.com 


\section{INTRODUCTION}

Strong and committed Human Resource can become the reflection of the strength of the organization. Employees are an important asset to differentiate an organization with other organizations (Azzolini and Shillaber 1993) . Qualified employees will become a competitive advantage for the organization, because it puts a human as a priority to improve the organizational goals (Fonseca and Verma 2001). Thus, the success and failure of an organization does not depend on the equipment, machinery or other materials, but rather on human resources (HR). Therefore, recruiting and retaining qualified and highly competent human resources is a critical point for the organization to succeed in global competition.

For organizations to maintain superior human resources is not always easy when organizations do not fully understand HR. Disgruntled employees often ended with resignation. For the company, the employee's resignation is a serious problem which if not handled properly can have an impact on the decline in productivity and the high cost of recruitment and training. Resignation can also cause a loss of opportunity (opportunity cost) for the loss of intangible assets owned by employees such as creativity and innovation.

$\mathrm{HR}$ is not the same as other capital, in addition to having the knowledge, skills and abilities that can be upgraded continuously, HR also has needs, desires, feelings, and other aspects that has influence in his/ her life. Disruption of a single aspect of human life can interfere with other aspects such as the behavior and performance. In the end, the disruption of these aspects may also affect the performance of the organization. Individuals will be able to work effectively if his/ her thoughts and feelings are comfortable and balanced (Hudson 2005; Lewison 2006). In order for the HR to work with high-yield or performance then they should be treated as a whole person in which the physical, mental and mind are in the same focus. To that end, HR should always be in the Work Life Balance, abbreviated as WLB.

WLB is the ability of each individual in finding a rhythm that will give them the opportunity to combine responsibilities of the work and responsibilities outside of work, activities and aspirations regardless of age and gender boundaries (Felstead et al . 2002) . So, WLB is an issue that covers all individuals, who earn a salary to do the job, regardless of whether they have family responsibilities or not. WLB is broadly defined as a satisfactory level of engagement or ' fit ' between the various roles in one's personal life. From the definition and the differing perspectives, WLB is generally associated with balance or improvement in harmony of life (Hudson 2005).

Currently, female workers are not inferior to men in which their skills and knowledge are relatively the same even some companies with female directors have better performance as Mc Kinsey survey 2007:2008; Catalyst 2007; Conference Board Canada, 2002 (Zallevski and Kirkup 2009). However, the dual role conflict felt by working women have become a topic of interest. On the other hand, in the face of dual roles conflict, sometimes women prefer to spend time caring for children rather than working outside the home (Betz and Fitzgerald 1987). Although the study results do not necessarily indicate the working hours of women are bigger than men (Burda et al. 2007), apparently it can not be denied that career women are more likely to spend more time working outside the home. Therefore, the amount of housework a woman does certainly be one of the factors that can interfere with activities in the workplace. To overcome this issue, many households, especially in Indonesia divert their homework by paying domestic labor. The transfer of household tasks with confidence can become a solution to overcome the problem of career women in their dual roles.

Although WLB is largely determined by individual domains and a complex and dynamic environment (Crooker et al. 2002), the organization is also a determinant in the realization of WLB. WLB programs implemented by a company for its employees have been chosen to become an important issue in researches. In developed countries, the support of organization for WLB is done by providing flexible work schedules, job sharing, completing office work at home using the internet facility (telecommuting) (Breugh et al. 2008). Other things that can be done by giving bonuses ( benefits), health and fitness facilities, child care and support for older people (elderly ), and sick leave policies , child care leave (Koppes 2008; Warren et al . 2009). In this research, support from organization to the employees will be investigated whether it can improve the WLB and be called the Organizational Support Practices (PDO).

Based on research conducted by Lewison (2006) in New York, the facts showed that more than $25 \%$ of workers stated that WLB is more important than competitive wages or job security. In addition, it is evident that more than $25 \%$ of employee absenteeism are caused by family problems. Therefore, work-life balance as discussed can make an impact / positive output (Hogarth et al. 2000). Many researchers have been relating it with increased job satisfaction (Malik et al. 2010; Aryee et al. 2005), career success (Nikandrou et al. 2008), and decreased turnover intention (Lazar et al. 2010). The positive impact of this becomes important because human resource is a strategic function within the organization for competitive advantage. Thus, better WLB condition is expected to improve the intention to stay in the organization for a long time.

Related to the discussion of WLB, this study is conducted on women employees who work in the banks in Jakarta. Bank is chosen as the research object because the author wanted to examine how WLB can be felt by bank employees working with routine work and the time is tight and with a complex work design. Thus we can get a picture of how women's careers in the best performing Bank perceives the WLB which can increase Intention to Stay. 


\section{RESEARCH PROBLEMS}

With complex conditions of life faced by women working in Jakarta, this study tries to analyze how individuals and organizations are influential in creating WLB which can increase the intention to stay working for women in the best performing banks in Jakarta. Therefore, this research is expected to produce findings that are beneficial to many parties and generate managerial implications.

From the above, the problem of this study is: "How WLB with organization support and individual efforts can positively influence the intention to stay among female employees in the best performing banks in Jakarta."

\section{Theoretical Framework and Hypothesis Development}

Work as stated in English is understood in context of paid employment while life covered the activities outside work. Balance in this matter covered physics and psychologist meaning as body or thought. Therefore balance can be measured or mean as an objective and subjective (Guest 2001). In (Guest 2001) some discussions about WLB more emphasized balance related towards Dual Role in family. WLB is really influenced by the high and low of work-life conflict which is conflict appears as multi role demand in life. Work-life conflict happens as mutually exclusive role done individual in a good life environment between individual, family and social environment in the work-life. Therefore, it is need organization support and individual ability (career women) in managing their Dual Role.

\section{The Influence of Organizational Support Practices (PDO) on WLB}

Work and life is in fact integrated (Sonnenfeld and Kotter 1982). In working life it is impossible to ignore the life side which became part of the image of an employee. Therefore, it should be the responsibility of the organization for facilitating the presence of WLB. Many advanced companies considered the issue related to work and life and strive to care by facilitating job satisfaction to reduce the rate of turnover. Some measures can be done, such as with family friendly policies. These policies are known to have positive results for the job satisfaction of employees on the technical level as well as commitment, turnover and absenteeism (Finegold et al. 2002). Organizations can affect WLB is by programs that can provide a solution to the dual role conflict of career woman.

Research on programs that support the WLB has been extensively done in developed countries but not in Indonesia. These programs, among others, providing a positive flexible working hours to decrease work family conflict, job sharing, or telecommuting (Breugh et al. 2008; Russell et al. 2009). Support provided by various programs have been widely studied such as flexible working hours, parental leave (Scandura and Lankau 1997; Lewison 2006), home working, teleworking (Quesenberry and Trauth , 2007) and so on. Other components can be done by giving bonuses (benefits), health and fitness facilities, child care and elderly care assistance, and a sick leave policy, including support for the family time and opportunity to develop one's career (Koppes 2008). The aim is for the employees have the opportunity to be able to balance the demands of work and activities outside of work or feel WLB.

Hypothesis 1: The Higher the Organizational Support Practices the Higher the WLB Perceived.

\section{Effect of Management of Dual Role (MPG) on WLB}

The complexity and dynamism of life is highly dependent on the mechanism facing each household and how they try to solve it. Other issues can include health problems, children's activities outside of school, mental health and the presence of family members with disabilities enhanced the need of managing family activities, access to employment and community support. The complexity of life in the family would have an impact on the activities of individuals in the workplace. This complexity often associated with pressure faced by career women with their dual roles (Crompton and Lyonette 2006; Crooker et al. 2002) that often makes them want to stop working (Schilling 2012).

The complexity and the pressure came from the home and extended to family environment (Blegen et al. 1988), for example the increasing number of family members so that the scheduling activities become more dense. The presence of family members who are still toddlers adds the activity to take care of and watch them (Shellenbarger 1998b; Voydanoff et al. 1988). Taking care of elderly family members who either live together or not, is a growing issue comparable to such issue as baby boom (Bond et al. 1998; Rachor 1998; Shellenbarger 1998a). Sharing of domestic roles in several studies that attempts to raise the issue of how housework can be a conflict seems to relate it with gender issues in which the husband with the traditional view is relevant to the increasing dual role conflict (Ahmad 1999).

In addition, the solution in a dual role conflict may engage the services of a housekeeper /baby sitter, laundry and other services may also be an option. For the case in developed countries, workers were got from outsourcing services (Ruijter 2004). The use of outsourcing can be a concern because of trust issues. One of the reasons of concerns is whether the hired workers were able to do household chores well and replace the role of a housewife. This problem may occur because the worker suppliers do not necessarily provide outsourcing services that have the skills in house cleaning, cooking, and taking care of other needs (Ruijter and Lippe 2007).

The difficulty of dividing roles outside and inside the house always leads to a conflict. A conflict of work at home and in the workplace can occur because individuals often have too much workload while the time to do them is very limited (Frone et al . 1997b ; Voydanoff 2002) Kossek et al . (1999) in their article states how employees choose strategies to integrate work and family roles based on the influence of different conditions and references. The reference such as employer expectations, and understanding of family members of the boundary of the scope of work and family roles. 
With a good management of domestic work by transfer to the other party or sharing tasks with spouse, so that career woman is expected to resolve conflicts between work outside the home and housework. The presence of a housekeeper can overcome some of the assumed role conflict. Management of dual roles (MPG) is assumed to increase the WLB. When MPG can go well then a career woman is believed to be able to perform its role as both a housewife as well as in her profession at work with WLB.

H2: The Better the Management of Dual Role (MPG) the Higher the Work-Life Balance.

\section{The Organizatinal Support Practices (PDO) Influence on Intention to Stay}

Organizational support is needed by employees in order to work well, and is one of the determining factors that make them feel at home or want to stay longer in the organization (Tourangeau et al. 2012). Therefore PDO is determining factor of the intention to stay.

Research conducted by Malik et al. (2010) on doctors who work full time in different hospitals found that job satisfaction is negatively correlated with turnover intentions and burn-out, while support for WLB have a positive relationship with job satisfaction, and negatively related to burnout and turnover intentions. Negative correlation means that turnover intention is assumed to be positively correlated to the intention to stay. Theoretically, according to Szostak in Fonseca and Verma (2001), the inability to balance between work and family responsibilities, can influence the decrease in employee performance, increased absenteeism, increased turnover, low employee morale, increased problems and conflicts in the workplace. In other words, the better WLB perceived by a career woman, the more want she to stay working in the organization.

Hypothesis 3: The Higher the Organizational Support Practices Given, the Higher the Intention to Stay Perceived.

\section{Effect of Management Dual Role (MPG) on Intention to Stay}

For career women a sense of bigger responsibility for housework becomes one of the factors that interfere in conducting their the job or profession (Ahmad 1999; Sullivan \& Lewis 2001; Perrons, 2003; Kasearu 2009; Waren et al. 2009; Lewis and Campbell 2008; Aryee et al. 2005) although the actual domestic duties are care work that can be shared with family members (Eichler and Albanese 2007). In order to conduct a career well, then women should manage their dual roles in a certain way. Domestic chores can be done before and after work, share with spouse or use the service of a housekeeper (Waren et al ., 2009). Accordingly, career woman can continue to play a good role in and outside of the workplace.

Thus, managing dual roles for women can be done with a variety of options and one of them is to share with spouse. Nevertheless, most families are still adhered to the traditional view that domestic duties are considered the responsibility of a housewife (Sullivan \& Lewis 2001), especially in developing countries such as Indonesia. This view will force women to succumb to their husband's career, so that women often prefer to quit his job. Ability to manage dual roles is assumed to increase the intention to stay because of the ability to cope better with role conflict (Schilling 2012; Clem Herman 2006; Crompton and Lyonette, 2006).

H4: The Better the Management Dual Role the Higher the Intention to Stay.

\section{WLB influence on Intention to Stay}

Some studies suggest that WLB support practices can be used to retain high quality employees, increase employee morale, commitment and satisfaction, reducing problems of work and stress, improve the ability to recruit and retain talented and valued employees (Cappelli 2000).

WLB is also expected to positively influence the intention to remain or stay in the organization (Sanjeevkumar 2012). Intention to stay is the desire to stay/ endure in the company in the long run. Intention to stay in the company can be caused by various factors, including WLB and career success (Hurley et al . 2003; Stroh et al . 1996; Trenbunsel et al . 1995). The intention when maintained will allow a person to spend a lifetime career in chosen organization. The inability in balancing between work and family responsibilities can influence the level of absenteeism and turnover (Fonseca \& Verma , 2001). This is supported by research conducted by Sanjeevkumar (2012), which states that the positive effect WLB with Intention to Stay in Public Sector. He states that Career Opportunity has a positive relationship with employees ITS. Other research supports their results are also presented by Lazar et al. 2010 in which it was stated that the result of research Kanexa Research Institute (2007) confirms that WLB can lower intention to leave because the employee feels comfortable with WLB and proud of the organization as a satisfying place.

Hypothesis 5: The Higher the WLB Perceived the Higher the Intention to Stay.

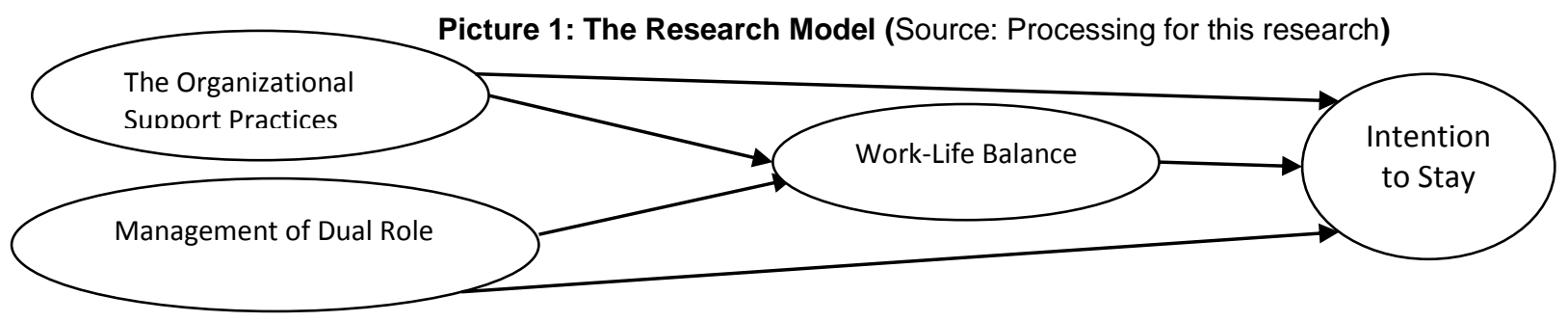




\section{RESEARCH METHODS}

\section{Population and Sample}

This study was conducted on female respondents who worked as bank employees. Selection of female respondents are based on the premise that women usually have the constraints in the career given their big role in taking care of the household, especially in Indonesia, which still has a traditional view of gender (Hadiz and Eddyono, 2005). However, nowadays women who have dual roles can become a successful career woman. Selection of the banking industry as the research object is based on the assumption that the work at the Bank requires regular working hours, which are generally from 8 am to $5 \mathrm{pm}$ with the complexity of the tasks that are relatively high. The characteristics of this industry typically face more complex WLB problems. The research was conducted in the best-performing banks based on Info Bank magazine. The top 10 bank for the year 2012 were chosen, but only 8 were because 2 of them are foreign banks.

The sampling method does is a non- probability sampling (purposive sampling). Nonprobability sampling method conforms to certain criteria (Cooper and Schindler 2000). Respondents (sample) in this study were women who is working, married, have children, and worked for at least 3 years, 3 years criteria meant that the respondent has passed the orientation and can provide a more representative answer because she has been able to follow a career development program .

The population of this study were all female employees who had been married and have a child in banks with best performance. Total population of this study is relatively difficult to know because the data of married female employees are usually hard to come by considering the sample is women with certain criteria. Taking into account the time and cost, the researcher would not count the number population of the study. Questionnaire will be distributed to 300 respondents. Determination of the number of samples is based on calculations by Yamane (1973) in (Ferdinand 2006). Based on calculations using Yamane formula, the sample size of 267 was set. But, in anticipation that the questionnaire may not be fully filled 300 samples were taken. Also according to Roscoe (Sekaran 2000), in multivariate research (including multiple regression analysis), the sample size should be several times (10 times or more) the number of variables in research. Sampling technique chosen was convenience sampling with accidental method in which researcher will go to the banks in question and distribute questionnaires to potential respondents based on pre-determined criteria. The respondents chosen were candidates found during the visit or respondents allowed by the company to complete the questionnaire.

The questionnaire makes in 1 to 10 scales and inserted by open questions as an additional information support. Validity testing done by using analysis factor. The hypothesis testing used Structural Equation Modeling. It is chosen because SEM is a proper model to test the relation simultaneously for latten variable represented by their indicators.

The questionnaire was made on a scale of 1 to 10 and accompanied by an open question as additional supporting question. Validity testing is done by using factor analysis. Testing the hypothesis of the study as described in the research model using Structural Equation Modeling. SEM model was chosen because it is most appropriate model to test for the simultaneous relationships of latent variables represented by the indicators. The test was performed using AMOS software version 21.00.

\section{Operationalization of variables:}

1. The practice of organizational support (PDO) is the support given by organization to the employees so that working women have the intention that remains high for a career in the organization. Indicators of these variables are: regulatory (PDO1), policy and counseling (PDO2), career planning program (PDO3) (developed from Koppes 2008) . Indicators of family friendly policies support practices are not included because in preliminary study it turns out that respondents said the program is not available in their organization.

2. Dual role management (MPG) is the attempt by career woman to manage dual roles in such a way that using the services of a housekeeper (MPG1), working on her own (MPG2), and share with a spouse (MPG3) (developed from Waren 2009).

3. WLB is a condition felt by career women in work and life as a balance of work and family (WLB1), work and social community (WLB2), work and leisure for themselves (WLB3) (developed from Crooker 2002; Hudson 2005).

4. Intention to stay (ITS) is the intention of career women to continue in organizations, want to work in the long run in the organization (ITS1), want to spend a career until retirement in an organization (ITS2) and want to be part of the best-performing organizations because of being satisfied (ITS3) (developed from Lazar 2010) .

\section{RESULTS AND RESEARCH FINDINGS}

Obtained from questionnaires distributed, data characteristics of the respondents as follows : 1) more than $70 \%$ of respondents and spouses have the undergraduate education, and the rest are master and diploma; 2)most of the 73 $\%$ of respondents have 1 or 2 children; 3 ) more than $80 \%$ of respondents are $30-50$ years of age ; 4) $80 \%$ of respondents earn more than Rp. 5 million; 5) $40 \%$ of respondents are managerial employees and the rest are nonmanagerial. 
From the questionnaire answers it is known that career women in this study responded to agree in a relatively high average of $>7$ for all study variables. Respondents highest average fall in variable ITS illustrating that women employees in the best performing banks have a desire to stay which is high, especially because of being proud of the organization. From the answer also we know that the dual role received the highest average on the answer using domestic services, and is also relevant to the answer to the highest WLB is on work and family balance . This means that the respondents with dual role problem can be solved by attempts to divert to domestic services. Description of results can be seen in the following table.

Table 1: Description from Questionnaire

\begin{tabular}{|l|l|l|l|l|l|}
\hline Indicator & $\mathrm{N}$ & Min. & Max. & Mean & Std. Deviation \\
\hline PDO1 & 154 & 5.00 & 9.00 & 7.1948 & .85618 \\
\hline PDO2 & 154 & 5.00 & 9.00 & 7.2468 & .89524 \\
\hline PDO3 & 154 & 4.00 & 9.00 & 7.0779 & .93258 \\
\hline MPG1 & 154 & 6.00 & 9.00 & 7.3312 & .73258 \\
\hline MPG2 & 154 & 5.00 & 9.00 & 7.2922 & .67568 \\
\hline MPG3 & 154 & 6.00 & 8.00 & 7.1494 & .71201 \\
\hline WLB1 & 154 & 5.00 & 9.00 & 7.4091 & .71960 \\
\hline WLB2 & 154 & 5.00 & 9.00 & 7.1104 & .78849 \\
\hline WLB3 & 154 & 5.00 & 9.00 & 7.0455 & .82716 \\
\hline ITS1 & 154 & 6.00 & 9.00 & 7.3636 & .69375 \\
\hline ITS2 & 154 & 6.00 & 9.00 & 7.5065 & .72533 \\
\hline ITS3 & 154 & 6.00 & 9.00 & 7.5584 & .77533 \\
\hline
\end{tabular}

Source: Processing for this research

Where as: PDO (Praktek Dukungan Organisasi): The Organizational Support Practices; MPG (Manajemen Peran Ganda): Management of Dual Role ; WLB: Work-Life Balance; ITS: Intention to Stay

From the results of the confirmatory test it is known to all the requirements of goodness of fit has been fulfilled as did the normality of the data. Hypothesis test results also showed hypotheses 1,2 , and 4 are significantly positive and can not be rejected, hypothesis 3 was not significant at alpha $5 \%$, however, for hypothesis 3 is still acceptable in alpha $6 \%$ and hypothesis 5 should be rejected. Here are the results of testing hypotheses by SEM and AMOS software version 21 .

Table 2: Hypothesis Testing Result

\begin{tabular}{|lll|l|l|l|l|l|}
\hline \multicolumn{2}{|l}{ Hipotesis } & & Estimate & S.E. & C.R. & P & Label \\
\hline WLB & $<---$ & PDO &, 4714 &, 1762 & 2,6752 &, 0075 & par_8 \\
\hline WLB & $<---$ & MPG &, 4011 &, 1825 & 2,1982 &, 0279 & par_12 \\
\hline ITS & $<---$ & PDO &, 3233 &, 1725 & 1,8746 &, 0608 & par_7 \\
\hline ITS & $<---$ & WLB &, 3376 &, 1185 & 2,8491 &, 0044 & par_13 \\
\hline ITS & $<---$ & MPG &, 2043 &, 1632 & 1,2519 &, 2106 & par_14 \\
\hline
\end{tabular}

Source: Processing for this research 
Picture 2: Structural Equation Model Full Model Standardized Estimates

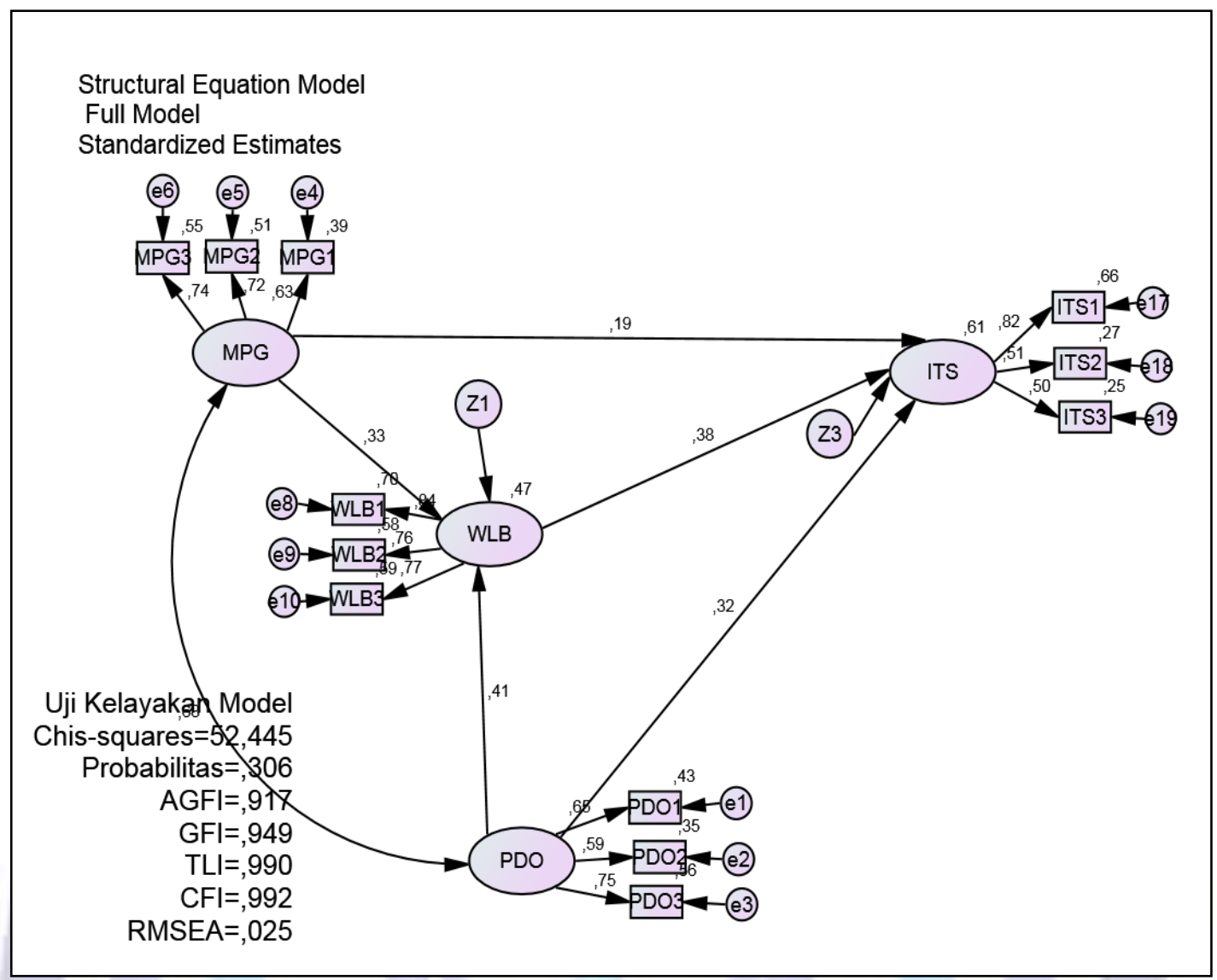

Source: Processing for this research

\section{H1. The Better Dual Role Management the Higher Work-Life Balance Felt}

Dual Role Management described by the ability in managing Dual Role by using housemaid service, sharing with couples, and doing herself in fact are significant influenced WLB, with C.R. 2,1982 and P 0,0279 and estimation coefficient relative 0,4011 . Dual Role cannot be denied to become one of the obstacles for career women in working out of home. Dual Role was often not realized to be a problem, because Dual Role is assumed to be women nature as reproductive employees.

From the questionnaires known that career women have the more family complexity where mostly children are still needed supervision and attention (more than 90\%) in accordance with Shellenbarger (1998b); Voydanoff (1988). It is showed the respondents family situation are still in high complexity because they are in dynamic family life situation (57\% respondents are below 40 years) relevant with Blegen et al (1988). Besides, those respondents are also involved in giving attention towards old family members. More than $65 \%$ respondents stated that they have old parents who needs to care about Bond et al. 1998; Rachor 1998, Shellenbarger 1998a). Therefore, these complexity and dynamic life of respondents are giving more role conflict.

Life complexity in family influenced the individual activity in working place. It is often related to the pressure face by career women with their Dual Role (Crompton and Lyonette 2007). Therefore, this research shows that the respondents can do their Dual Role such as by sharing with spouse and using the housemaid service. This ability to manage in fact can increase WLB. The housemaid role is so high in overcoming Dual Role conflict, indicated in respondent's answer who will take some leave if the housemaid is absence.

There is an interesting finding, that women in big city like Jakarta, especially for the respondent's family known to be able to share domestic role with spouse. It is done by the respondents who agree that the household chores can be done together. Therefore, the husband has an egalitarian view towards gender. It is possible because mostly the respondents' families are highly educated, so the points of view in handling gender issue are widen and open. This research is relevant with Ahmad (1999) in Malaysia about domestic role sharing. This research is also supported by Quesenberry and Trauth (2007 who found that if a woman who holds her husband's traditional role of developing needs of work and family in the conflict will intensify. Relevant to this study, women may feel high WLB and also be supported by sharing the role with a spouse in their domestic roles.

The authors conclude, the problem of dual roles for women in this study did not become an obstacle in the career because of the ease of obtaining PRT as a service that can handle tasks in addition to the support of spouse who shares domestic tasks. Household work outsourced with trust becomes a solution for career women with their 
dual roles. It is compatible with Warren (2009) that the ability to manage Dual Role can be as solution. The house maid existence in fact can overcome Dual Role conflict and give significant contribution towards WLB. The hypothesis testing result shows the regression coefficient for MPG is the highest coefficient which influenced WLB.

\section{H 2: The Better the Organizational Support Practices (PDO) the Higher Work-Life Balance Felt}

In undertaking WLB, organization can provide employee care program or PDO. From the estimation parameter of PDO towards WLB shows significant result with score C.R 2,6752 and P in level 0,0075 it is shown there is positive PDO towards WLB with a strong estimation coefficient 0,47 in alpha $5 \%$.

From the results of research conducted PDO apparently responded with a high index, some practices of support for women in resolving the conflict of dual roles has not been a concern of the best performing banks studied For example, the unavailability of childcare, as well as breastfeeding room, unavailability of parental leave, and family friendly programs are also not available. Nevertheless, the practice of support program such as career planning, counseling complaints and problems, health benefits and handling of accidents and safety has been running well. In preliminary research (pretest) indicators of support program such as facilities and family friendly flexible working hours, teleworking and homeworking also included as an indicator, but because almost all of the answers are on a scale of 1 in 10 and many answers were left blank then the item is dropped and only included as supporting data. This can be understood as a description of the work in a bank is difficult to be done with flexible working hours, and home working. However, for the part of the child care facility, the organization should have pay attention.

PDO indicators such as the regulations generally responded well to the regulation of leave, hours of work hours of eating and resting, or prayer with a high index. From the data, it is known that the banks with the best performance has implemented regulations in accordance with applicable employment laws. Rules of leave, hours of work and occupational safety and health assurance has also been going well.

However, it has been put forward as supporting data that almost all respondents state that company does not provide support facilities pertaining to dual roles such as child care, breastfeeding and healthy canteen space and also other WLB programs such as flexi-time, telecommuting, work from home, parental leave, scheduling and others.

\section{H3: The Better the Organizational Support Practices (PDO) the Higher Intention to Stay}

From the hypothesis 3 it is known that PDO is not significant to influence Intention to Stay in level $5 \%$ alpha but by score P 0.0608 PDO still influence to increase intention to stay. For social problems in research alpha $10 \%$ still can be considered to see this influence. Organization support becomes one of the variables to increase women staff intention to stay in organization in long term. This support mainly related towards career women Dual Roles which can be given in facilities or family friendly policies programs. This is relevant by the researches stated that many women choose to stop working when she is not able to overcome Dual Role conflict (Schilling 2012; Herman 2006; Aryee et al. 2005; Crompton and Lyonette 2006).

\section{H4: The Better Management of Dual Role (MPG) the Higher Intention to Stay (ITS)}

Hypothesis 4 is MPG can increase ITS in fact cannot be proved to be significant. Dual Role management which is an individual effort to stay in organization in other words MPG is not influences towards ITS. This research does not support the result (Schilling 2012; Crompton and Lyonette 2006; Warren et al. 2009). it is showed that women staffs intention to stay in organization is not related to whether the domestic role dine alone either share together with couple or deliver it to the house maid.

Some things are related to insignificant result, based on the writer as follows: 1) career women work in the best performance banks have higher ITS caused by aims and proud to work as a willingness to keep up and not influenced by MPG; 2) In developing countries like Indonesia is difficult to get a job makes they commit to organization is higher. Therefore, this explanation still needed more research.

\section{H5 : The Higher WLB the Higher ITS}

This research proved that WLB is significant to increase Intention to Stay with score C.R 2,8491 and P 0,0044 with relative estimation coefficient are middle 0,34. It is showed that WLB becomes one of important thing to be concerned by organization since it can make staffs want to stay in organization which means decrease turn over. As what has been discussed high turnover can increase recruitment cost and also lose of competence human resource. Better WLB percept higher Intention to Stay, this research supports the former research (Sanjeevkumar 2012; Lazar et al. 2010; Malik et al. 2010).

This research proved that WLB as the main factor for career women in willing to stay in organization in long term. Therefore, it is needed to increased support towards the antecedent variables from WLB such as PDO from organization domain and MPG from individual domain is proved significant increasing WLB.

\section{DISCUSSION}

Although the hypothesis testing result proved that each of PDO and MPG has a positive significant influence on WLB, but this result still to be an interesting discussion. Organization support practice to overcome Dual Role conflict is not concerned by organization. It is related to the ease of transmitted Dual Role to housemaid. As what explained before, transmission roles to housemaid can give worthless impact in children care and care work (Ruijter 2004). Besides in 
the future, housemaids will be rare to have. If education and economic in Indonesia getting better there will be difficult to get housemaid service which impact to Dual Role management.

This research also shows the effort to manifest WLB perceived by women staffs in bank with the best performance, comes from individual where there is no support for WLB program from organization. The support only for counseling which is indicated by the staffs that has problems in working. It is strengthen by Dual Role management and the solution is chosen personally using housemaid service.

The other research shows that Dual Role management in fact, cannot influence intention to stay. It is showed staffs that have willingness to stay in organization not because of able to handle Dual Role but it is caused by other factor. The writer estimated the other factor is proud. The aim of staffs to work in the best performance organization becomes the determinant if staffs want to stay in organization. Therefore, it is still has to be proved by the coming research.

From this research, there are some managerial implications. Working in banking industry as what realized that the possibility to work flexi time is difficult to be attained, as well as home working program or job sharing. But, other support programs can be done. From the data it is noted that the burden of working in a bank is very high, the respondents are living far from the work place, there is no childcare facilities, parental leave days is not managed, so the writer thinks that support to Dual Role it is supposed to be done by : 1) developing an effective working method therefore the working time is short; 2) company can provide comfortable pick and leave for the women to avoid tiredness and difficulty to get transportation relating with the traffic in Jakarta; 3) providing supporting facilities related to Dual Role such as childcare, breast feeding room, healthy canteen; 4) making the rules of parental leave days which is needed when women are faced by certain condition in caring children.

From the research it is recommended, it is time for the companies in Indonesia to pay attention to WLB programs since WLB solutions are so far come from the staffs. Government involvement is needed as the regulating side to make regulations about employment included WLB problems.

\section{REFERENCES}

[1] Ahmad, A. 1999. Gender role orientation of husbands and work-family conflict of wives in dual-earner families. Pertanika J. Soc.Sci. \& Hum. 7 (1):1-9.

[2] Aryee, S., H. HoonTan, and E. S. Srinivas. 2005. Rythms of life: Antecedents and outcomes of work-family balance in employed parents. Journal of Applied Psychology 90 (1):132-146.

[3] Azzolini, M., and J. Shillaber. 1993. Internal service quality: Winning from the inside out. In Internal Service Quality.

[4] Betz, N. E., and L. F. Fitzgerald. 1987. The career psychology of women. San Diego, CA: Academic Press.

[5] Blegen, M. A., C. W. Mueller, and J. L. Price. 1988. Measurement of kinship responsibility for organizational research. Journal of Applied Psychology 73:402-409.

[6] Bond, J. T., E. Galinsky, and J. E. Swanberg. 1998. The 1997 National Study of the Changing Work-force. Families and Work Institute.

[7] Breugh, J. A., N. Frye, and N. Kathleen. 2008. Work-Family Conflict: The Importance of Family-Friendly Employment Practices and Family-Supportive Supervisors. Journal Bus Psychool 22:345-353.

[8] Burda, M. C., D. S. Hamermesh, and P. Weil. 2007. Total Work, Gender and Social Norms. In IZA Discussion Paper No 2705. Bonn.

[9] Crompton, R., and C. Lyonette. 2006. Work-life 'balance' in Europe. Acta Sociologica 49:379.

[10] Crooker, K. J., F. L. Smith, and F. Tabak. 2002. Creating Work-Life Balance: A Model of Pluralism Across Life Domains. Human Resource Development Review 1 (4):387-419.

[11] Felstead, A., N. Jewson, A. Phizacklea, and S. Walters. 2002. The option to work at home: Another privilage for the favoured few? New Technology, Work and Employment 17 (3).

[12] Finegold, D., S. Mohrman, and G. M. Spreitzer. 2002. Age effects on the predictors of technical workers' commitment and willingness to turnover. Journal of Organizational Behavior 23:655-674.

[13] Fonseca, M., and A. Verma. 2001. Learning and Work-Life Balance in Canada: Evidence from the General Social Survey. Paper read at The CIRA XXXVIII Annual Conference at Quebec City Toronto.

[14] Frone, M. R., J. K. Yardley, and K. S. Markel. 1997b. Developing and testing an integrative model of the work-family interface Journal of Vocational Behavior 50:145-167.

[15] Guest, D. E. 2001. Perspective on the Study WLB. In ENOP Symposium. Paris.

[16] Herman, C. 2006. Achieving a harmonious work life balance: myth or reality? Experiences of women returning to work in science engineering and technology in the UK. In Science Policy Meets Reality Conference Prague.

[17] Hogarth, T., C. Hasluck, G. Pierre, M. Winterbotham, and D. Vivian. 2000. Work-Life Balance 2000:Results from the Baseline Study. In Research Report RR249: Departmen for Education and employment.

[18] Hudson, A. 2005. The case for work/life balance: Closing the gap between policies and practice.

[19] Koppes, L. L. 2008. Facilitating an organization to embrace a work-life effectiveness culture: a practical approach. The Psychologist Manager Journal 11:163-184.

[20] Kossek, E. E., R. A. Noe, and B. J. DeMarr. 1999. Work family role synthesis: individual and organizational determinants. The International Journal of Conflict Management 10 (2):102-129.

[21] Lazar, L., C. Osoian, and P. Ratiu. 2010. The role of WLB practices in order to improve organizational performance. European Research Studies 13 (1). 
[22] Lewison, J. 2006. The work/life balance sheet so far. Journal of Accountancy 202 (2):45.

[23] Malik, M. I., F. Salem, and M. Ahmad. 2010. Work-life balance and Job Satisfaction among doctor in Pakistan. South Asian Journal of Management 17 (2):112.

[24] Nikandrou, I., L. Panayotopoulou, and E. Apospori. 2008. The impact of individual and organizational characteristics on work-family conflict and career outcomes. Journal of Managerial Psychology 23 (5):576598.

[25] Quesenberry, J. L., and E. M. Trauth. 2007. The role of ubiquitous computing in maintaining WLB: perspectives from women in the information technology workforce Paper read at Proceeding in School of Information Sciences and Technology at PA U.S.A.

[26] Rachor, M. M. 1998. When worlds collide: Elder caregiving poses new challenges for balancing work and life. Employee Benefits Journal 23 (3):20-23.

[27] Ruijter, E. D. 2004. Trends in the outsourcing of domestic work and childcare in the Netherlands: compositional or behavioral change? Acta Sociologica 47 (3):219-234.

[28] Ruijter, E. d., and T. v. d. Lippe. 2007. Effects of job features on domestic outsourcing as a strategy for combining paid and domestic work. Work and Occupations 34:205-230.

[29] Russel, H., P. J. O'Connell, and F. McGinnity. 2009. The impact of flexible working arrangements on WorkLife conflict and work pressure in Ireland. Gender, Work, and Organization 16 (1).

[30] Sanjeevkumar, V. 2012. A Study on Employee's Intention to Stay in Public Companies, Kedah, Malaysia. Zenith International Journal of Business Economics and Management Research 2 (4).

[31] Scandura, T. A., and M. J. Lankau. 1997. Relationships of gender, family responsibility and flexible work hours to organizational commitment and job satisfaction. Journal of Organizational Behavior 18 (4):377-391.

[32] Schilling, E. 2012. Between security and professional exclusion: Career linearity and work-life-balance in German and Russian public administration. Cologne, Germany: University of Applied Administrative Sciences NRW.

[33] Shellenbarger, S. 1998a. Children make early plans to care for their elders. Wall Street Journal p.B1.

[34] 1998b. Futurework policies may focus on teens. Wall Street Journal p. B1.

[35] Sonnenfeld, J., and J. P. Kotter. 1982. The maturation of career theory. Human Relations 35:19-46.

[36] Tourangeau, A. E., H. Thomson, M. Saari, K. Widger, E. M. Ferron, and K. MacMillan. 2012. Determinants of nurse faculty intention to remain employed. Open Journal of Nursing 2:254-261.

[37] Voydanoff, P. 2002. Linkages between the work-family interface and work, family, and individual outcomes. Journal of Family Issues 23:138-164.

[38] Voydanoff, P., B. W. Donnelly, and M. A. Fine. 1988. Economic distress, social integration, and family satisfaction. Journal of Family Issues 9:545-564.

[39] Warren, T., E. Fox, and G. Pascall. 2009. Innovative social policies: Implications for work-life balance among low waged women in England. Gender, Work and Organization 16 (1).

[40] Zallevski, A., and G. Kirkup. 2009. The case for increasing gender diversity of company boards in science, engineering and technology (SET). In Research Briefing No. 12. UK: UK Resource Centre for Women in SET. 